\title{
Az élhető és az élhetetlen társadalom rendörsége
}

\author{
Recenzió Krémer Ferenc: Az élhető társadalom \\ és a rendőrség válsága. Alternatívák az autoriter \\ rezsimekre címú könyvéről
}

\section{SZAKÁCS Gábor ${ }^{1}$}

Nagy örömmel és érdeklődéssel olvastam Krémer Ferenc legújabb könyvét, ${ }^{2}$ amely szerves folytatása, kiteljesítése a Napvilág Kiadónál 2003-ban megjelent Rossz döntések kora és a 2010-ben szintén a Napvilág Kiadónál kiadott A rendőri hatalom természete című munkáinak.

Krémer három évtizede foglalkozik behatóan a rendészet kérdéseivel, a rendőrség szervezetével, kultúrájával, feladatteljesítésének rendjével, sajátosságaival, irányításának jellemzőivel, a politika, a jog, illetve a rendészet kapcsolatával és ezeknek a társadalom múködésére gyakorolt hatásaival. A most megismert tanulmány is számos tudományterület (szociológia, politológia, filozófia, jog, kriminológia, történelem, pedagógia) kutatási eredményeit felhasználva vizsgálja, elemzi és mutatja be a kutatott területet. Ez az interdiszciplináris problémamegközelítési mód nemcsak magyar, hanem nemzetközi viszonylatban is különlegesen értékessé teszi az ajánlott tudományos munkát. A fajsúlyos szakirodalmi háttérre és a szerző kutatási eredményeire támaszkodó írás egyedi fogalmi apparátus felállításával mutatja be az élhetőnek, illetve az élhetetlennek tartott társadalmak jellemzőit, a biztonság eltérő megítélését, az egymásnak feszülő politikai és rendészeti koncepciókat, a hatékonyság, az erő(szak), a veszély, valamint a titok mítoszainak kezelését, az ezekhez törvényszerűen igazodó rendészeti és kriminálpolitikákat, az együttmúködésre vagy az engedelmességre épülő intézményi viszonyokat, irányítási megoldásokat, az uralkodó szervezeti kultúrákat, a rendőrség helyének, szerepének meghatározásában mutatkozó eltéréseket, nem utolsósorban a rendőrség személyi állományának felkészítésében, fejlesztésében mutatkozó stratégiai különbségeket.

Az olvasó számára nem kétséges, hogy Krémer a kooperációra, a befogadásra, a kohézióra alapozó, élhetônek tartott társadalom, a több tényezőbool építkező, a személyes, valamint a közös biztonság különböző változatainak megvalósítása mellett, illetve

Dr. Szakács Gábor CSc ny. egyetemi docens

Gábor Szakács PhD, CSc. retired Associate Professor

https://orcid.org/0000-0002-8544-3112; g.szakacs@t-online.hu

2 Krémer Ferenc: Az élhetö társadalom és a rendörség válsága. Alternativák az autoriter rezsimekre. Budapest, Gondolat, 2020. 
a bezárkózással, a fragmentált identitással, a kényszerkohézióval operáló élhetetlennek nevezett társadalom, az egy tényezőre fókuszáló biztonságértelmezés és a politikai rendészet térnyerése ellen foglal állást. Álláspontját meggyőző filozófiával, logikus érveléssel, a feldolgozott kutatási eredmények, adatok, tények bemutatásával, a lezajlott folyamatok komplex elemzéséből származó következtetései közreadásával hitelesen osztja meg a téma iránt érdeklődőkkel.

Bizonyára sokan lesznek olyanok, akik a könyv elolvasása után és a jelen helyzet ismeretében azt gondolják, hogy az élhetőnek nevezett társadalom, az ehhez kapcsolódó politikai és rendészeti koncepció, a policing típusú rendőrségi tevékenység számos országban sikeresen működtetett formája Magyarországon - a szerző és más neves kutatók munkáiban foglaltakra is figyelemmel - utópisztikus gondolatnak, ezért kivitelezhetetlen elképzelésnek számít. Jómagam több mint 40 évet dolgoztam a közszolgálat különböző területeinél, ebből 34 évet a rendészetben, ezért azt gondolom, hogy az élhető társadalomra mint egy megvalósítható, megvalósítandó jövőképre kell gondolnunk. Hisz a körültekintően kidolgozott jövőkép - egyebek mellett - bizalmat ébreszt, együttmúködésre ösztönöz, kölcsönös egymásrautaltságot eredményez, motivál. Megérteti, hogy valamennyien felelősek vagyunk a kitűzött cél eléréséért, szem előtt tartva a kívánt végeredményt. Segít okos döntéseket hozni, valamint jó válaszokat adni a „Hogyan tovább?” kérdésére. Krémer az élhetetlen társadalom kritikai elemzése alapján részletesen megmutatja azt a jövőképet, amely hozzásegítheti a magyar társadalmat, a hazai rendészetet, a rendészetpolitikát a rendszerszerű és érdemi átalakuláshoz, a demokratikus elvek szerinti korszerü, élhető, professzionális múködéshez.

Peter Drucker osztrák származású amerikai menedzser a jövőalkotással kapcsolatban a következő találó kijelentést tette: „A jövőt úgy lehet a legpontosabban megjósolni, ha megteremtjük." ${ }^{3} \mathrm{Az}$ élhető társadalom, a policing típusú rendészeti tevékenység és rendészeti politika tehát nem utópia, hanem a szerző optimizmusát, jövőbe vetett hitét, reményét kifejező, kiszámítható, átlátható, megismerhető, együttműködésre, bizalomra épülő rendszer. Olyan átgondolt, racionális rendszer, amely bizonyította, illetve folyamatosan bizonyítja életképességét, és azt, hogy az élhető társadalomra jellemző metódusnak hosszú távon nem lehet alternatívája az élhetetlen társadalom.

Mindezek alapján meleg szívvel ajánlom Krémer Ferenc munkáját mindazoknak, akik akár az egyik, akár a másik, egymással rivalizáló politikai és rendészeti koncepció mellett foglalnak állást, mert a felsorakoztatott tények alapján tudományosan megalapozott visszajelzést kaphatnak álláspontjuk helyzetéről, lehetőségeiről, jövőválasztásuk mikéntjéről. A könyvet azért is érdemesnek tartom az elolvasásra, mert a szerző által használt fogalmi apparátus, ezek bemutatása, logikai összerendezése, a tudatosan alkalmazott „sarkos” megfogalmazás mind-mind arra késztethetik a politikusokat, a szakembereket, a kutatókat, hogy pro vagy kontra véleményt nyilvánítsanak, ismételten átgondolják álláspontjukat, új kutatásokba kezdjenek, felhasználják a közzétett

3 Peter F. Drucker: Drucker minden napra. Budapest, Manager, 2008. 20. 
érvanyagot napi problémáik megoldásához, közép- vagy hosszú távú stratégiai elképzeléseik realizálásához.

Végezetül pedagógusként ajánlom a könyvet azoknak a kollégáimnak, akik a közszolgálat valamely területén, beleértve a rendészetet is, az egyes oktatási formák és szintek feladatait ellátó intézmények valamelyikében tevékenykednek, ily módon felelősséget vállalnak a pályakezdők formálásáért és a személyi állomány fejlesztéséért.

\section{IRODALOMJEGYZÉK}

Krémer Ferenc: Az élhető társadalom és a rendőrség válsága. Alternatívák az autoriter rezsimekre. Budapest, Gondolat, 2020.

Drucker, Peter F.: Drucker minden napra. Budapest, Manager, 2008. 